\title{
LONG-TERM WATER DEMAND ASSESSMENT USING WEAP 21: CASE OF THE GUELMA REGION, MIDDLE SEYBOUSE (NORTHEAST ALGERIA)
}

\author{
Essia BOUDJEBIEUR ${ }^{1 *}$ (D), Lassaad GHRIEB ${ }^{2(D)}$ Ammar MAOUI $^{3 \text { (D), }}$ \\ Hicham CHAFFAI ${ }^{1}$, Zine Labidine CHINI ${ }^{4}$ 这
}

DOI: 10.21163/GT_2021.162.06

\begin{abstract}
:
The Guelma sub-basin, an integral part of the Middle Seybouse basin, covers a surface area of 818 $\mathrm{km}^{2}$, subject to subhumid climate. The main surface water reservoir is the Bouhamdane dam with a regulated volume of $55 \mathrm{hm}^{3}$. The main underground reservoirs are found in the aquifer systems of the Guelma plain, the Bouchegouf plain, the H'lia water table and the Heliopolis karst. To enable the rational use of water resources in the study region, integrated management of these resources remains essential. In this work we used WEAP 21 software (Water Evaluation and Planning), for the modeling of water resources, considering the year 2017 as the reference year for 2020-2050, with a base scenario "water demand". The results of the simulation show a significant water shortage of around $50.5 \mathrm{hm}^{3}$, marking a scarcity of the resource, noticed from the reference year 2017, because of the unfavorable climatic conditions which significantly impacted the water reserve in the municipalities of the watershed. This shortage will decrease to a volume of $31 \mathrm{hm}^{3}$ in 2024 , and $104.20 \mathrm{hm}^{3}$ in 2050 .
\end{abstract}

Key-words: water resources, integrated management, Middle Seybouse basin, climate change, WEAP21, water demand

\section{INTRODUCTION}

The discussion of aspects of the integrated water resources management is one of the major problematics raised in Algeria today. It is becoming an absolute necessity for a good management of water resources allocation in order to equitably satisfy the drinking water needs of the population and the economic sectors. (Zerkaoui et al., 2018, Al-Shutayri, et Al-Juaidi,2019, Alemu et Dioha,2020, Ali et al.,2014).

It is a vital necessity to maintain water resources in the face of increasing demands in agricultural, industrial and municipal uses. Production of crops and livestock is water consuming; agriculture aloneaccounts for $70 \%$ of all water consumption (www.unesco.gr). The world will need $50 \%$ more food supply for the population estimated at 9.5 billion for 2050 (Singh, 2014). It is estimated that the water consumption for both rainfed and irrigated agriculture will increase by approximately $19 \%$ by 2050. About $30 \%$ of fresh water on earth is stored in aquifers (Shiklomanov and Rodda 2003).

\footnotetext{
${ }^{1 *}$ University Badji Mokhtar, Water Resource Lab. \& Sustainable Development, 23000 Annaba, Algeria, a.boudjebieur@yahoo.fr, hichamchaffai@yahoo.fr

${ }^{2}$ University 8 May 1945, Water Resource Lab.\& Sustainable Development, 24000 Guelma, Algeria, ghrieblassaad@yahoo.fr

${ }^{3}$ University 8 May 1945, Civil Engineering and Hydraulic Laboratory, 24000, Guelma, Algeria, maouiammar@yahoo.fr

${ }^{4}$ University of Saad Dahlab Blida 1, Algeria, chini zine@yahoo.fr
} 
Since the late 1970s the occurrence of drought years increases in North Africa is presenting a major constraint to the future development of these regions. According to the IPCC conventions, a general decrease in rainfall together with a prominent surface heating can be expected for sub-Saharan Africa and north of the Sahara until 2050, resulting in further decreasing fresh water availability (Klose et al., 2008).

In Algeria, the multiplication of water needs linked mainly to the demographic expansion, the irrational exploitation of resources and the development of economic and agricultural activities has significantly increased the demand for water. (Kiniouar et al., 2017, Hamlat et al., 2013, Kahlerras et al., 2018).

Models are among the most useful devices in water supply management, and especially multiobjective modeling tools that involve stakeholders and facilitate decision making. They can be utilized in gathering data and improving the process of planning and managing the water supply systems (Sulis et Sechi,2013, Shahraki, et al.,2016, Lévite et al., 2003, Saadoun et al.,2014), combining physical and socioeconomic parameters. In the WEAP (Water Evaluation and Planning System) model (Stockholm Environment Institute 2005) standard linear programming is used for the water allocation problems.

Using WEAP a water planner can analyse a full range of water issuesthrough a scenario-based approach. Scenarios could include climate variability and change, watershed condition and changes, anticipated demands, ecosystem needs, the regulatory environment, operational objectives and available infrastructure (Yates et al., 2005 Husain et Rhyme, 2021).

The software, developed by the Stockholm Environment Institute, has shown its performance in many cases in terms of simulation for the choice of scenarios of development and management of the water resource in the medium and long term and decision-making which are needed (SEI 2008). This model is a decision support system (DSS) and provides a complete analysis of water supply and demand at present and estimation for the process in the future (Yazdanpanah, et al.,2008 Höllermann et al.,2010). This software is used when there is multipurpose and competitive demand and allows the analysis of different management patterns (Seiber, et al., 2005 Husain et Rhyme 2021, Xue et al.,2015).

The main objective of this study is to assess the impact of additional water demand in the Guelma region, Middle Seybouse, in long-term, using the Water Evaluation and Planning system (WEAP).

\section{MATERIALS AND METHODS}

\subsection{Description of the study area}

\subsubsection{Geographic location}

Covering an area of approximately $818 \mathrm{~km}^{2}$, the sub-catchment area of the middle Seybouse is located northeast of Algeria, $60 \mathrm{~km}$ south of the Annaba city between latitudes $36^{\circ} 14^{\prime}$ and $36^{\circ} 35^{\prime}$ north and longitudes $7^{\circ} 16^{\prime}$ and $7^{\circ} 44$ 'east, drained by the main stream which is the Seybouse which flows from west to east over a distance of $55.30 \mathrm{~km}$ (Fig.1).

The population was estimated at the end of 2017 at around 355,250 inhabitants, with a density of 334 inhabitants $/ \mathrm{km}^{2}$ (Algerian national statistics office 2008). The basin of the middle Seybouse is subject to a Mediterranean climate, rainy and cold in winter and hot and dry in summer. The mean annual rainfall for a 30 -year observation period is of the order of $615.8 \mathrm{~mm}$, with a mean annual temperature of around $18.26^{\circ} \mathrm{C}$.

From a hydrogeological point of view, this is a collapsing zone filled with very permeable alluvial deposits, which contains a significant water table supplied by infiltration water and by lateral contributions from the Seybouse watershed (Fig. 2). 


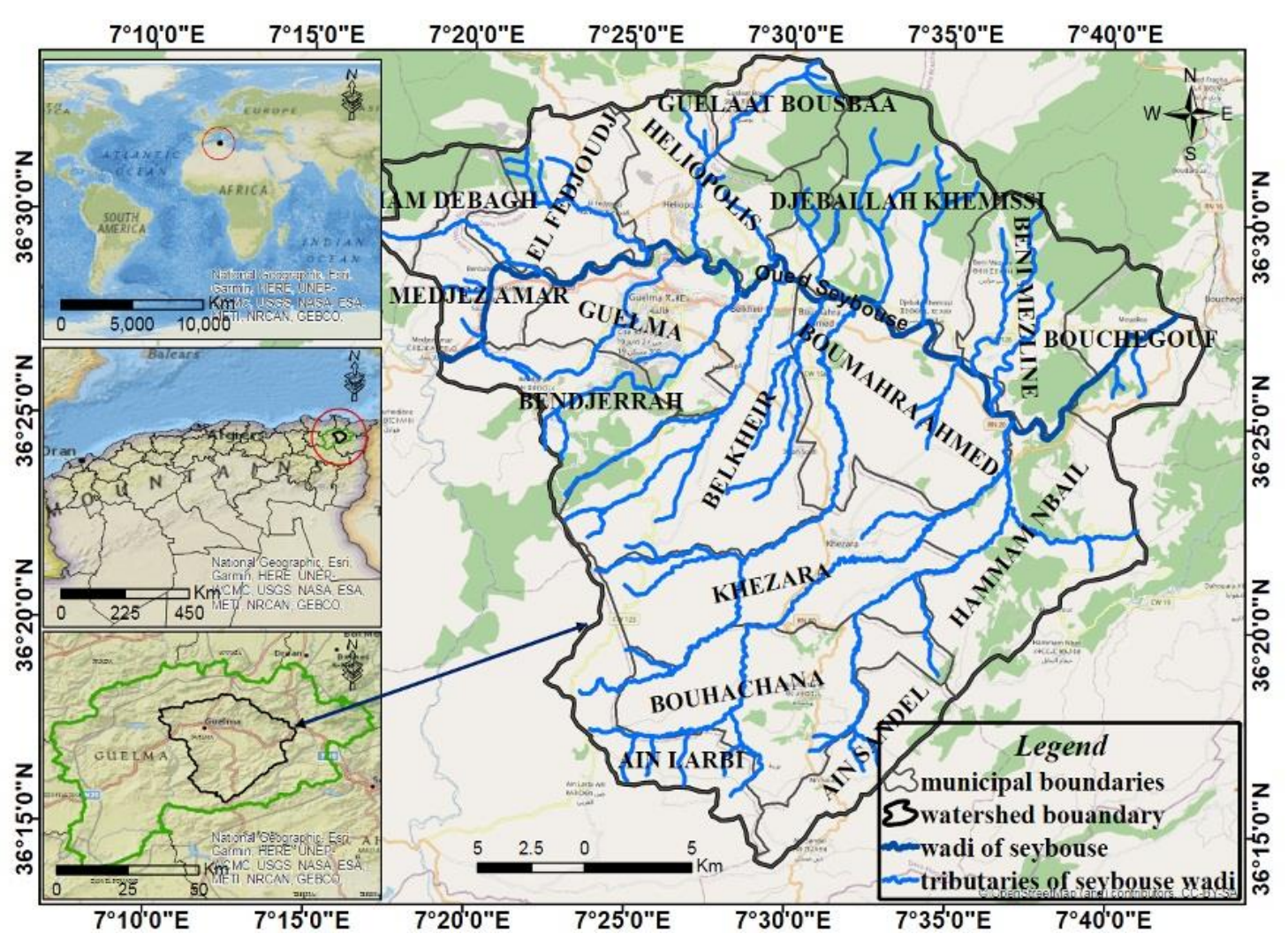

Fig. 1. Location map of the study area.

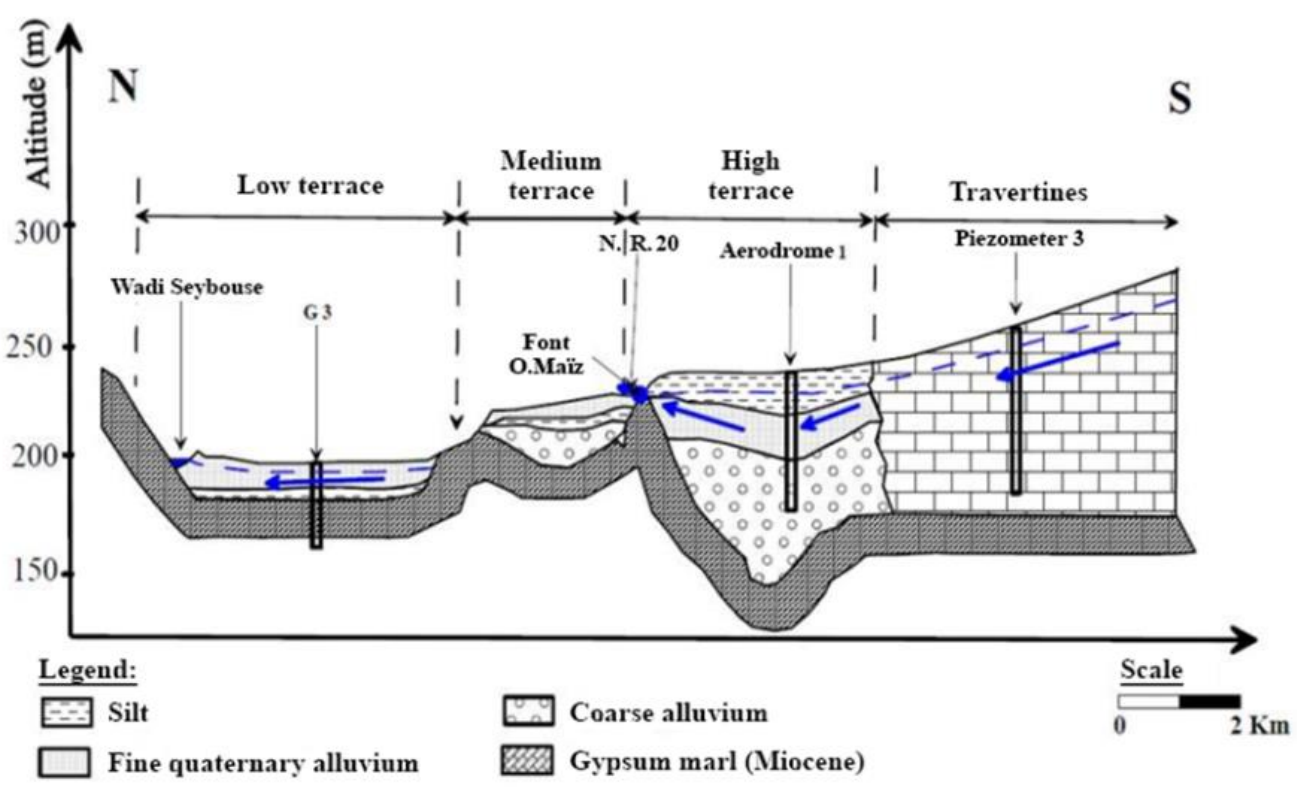

Travertines - - Piezometric level $\longrightarrow$ Direction of flow

Fig. 2. Hydrogeological cross-section in the study area (B. Gaud ,1974). 


\subsubsection{Distribution of water resources}

The population is supplied with drinking, irrigation and industrial water in the middle Seybouse basin, provided by groundwater extracted from the catchment areas of Héliopolis, OuedH'lia, the plains of Guelma and Bouchegouf with an estimated volume of $17 \mathrm{hm}^{3} /$ year, as well as treated water from the Bouhamdane dam, with a volume of more than $63 \mathrm{hm}^{3} /$ year, including $18 \mathrm{hm}^{3}$ / year for drinking water supply (four municipalities out of seventeen), and more than $45 \mathrm{hm}^{3}$ / year for the large irrigation scheme (Guelma-Bouchegouf) (Water Resources Department, 2018).

The distribution of drinking water in our study area encounters difficulties which make the management of these resources difficult (Fig. 3).

We can cite:

- the distribution time slots are insufficient in relation to the volume distributed;

- the delivery pipes are very old and generate a loss of more than $30 \%$ compared to the volume produced and distributed;

- the endowment is low compared to the Algerian standard.

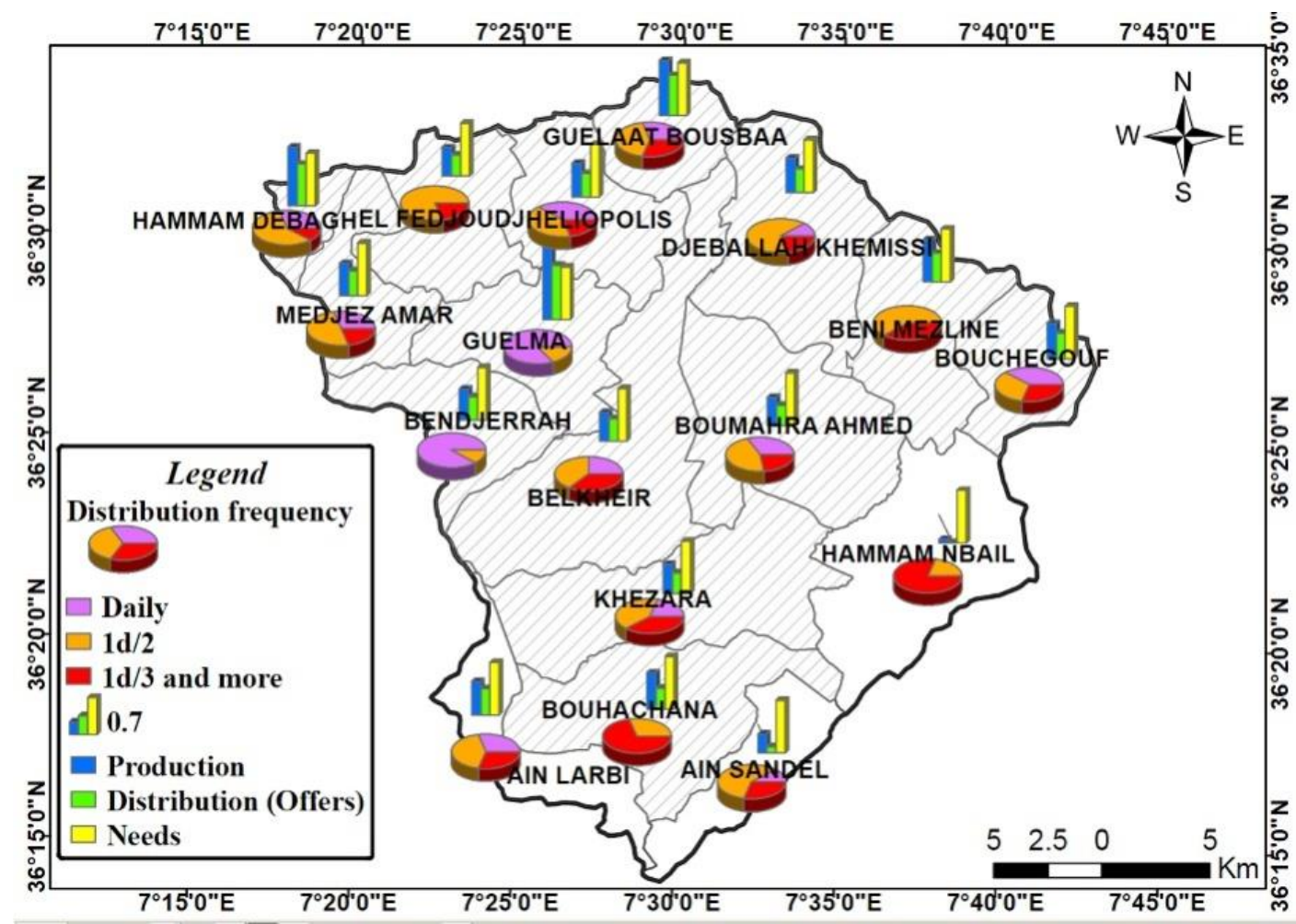

Fig. 3. Map of the production and distribution frequencies of water drinking water in the study area.

The irrigated perimeter, covering a surface area of 9,250 ha, also encountered several problems, mainly due to the mixed distribution network, which plays the dual role of backflow and distribution. The breakdown and dilapidation of this network in addition to frequent power cuts at pumping stations have reduced the volume allocated to irrigation to more than $35 \%$. The 2017 season irrigation campaign at the Guelma-Bouchegouf perimeter took place under exceptional conditions, given the drop in the water level of the Hammam Debagh dam, the main source of power for the perimeter which was deprived of power for the year 2017-2018. 


\subsection{Methodology}

The Water Assessment and Planning System (WEAP21) (http://www.weap21.org/), is a modeling and planning tool, developed by the Stockholm Environment Institute. It has enough flexibility to adopt different levels of data availability with a friendly graphical user interface. It is a useful tool for water resources management, which includes both water supply and demand issues, in addition to water quality and ecosystem preservation, such as required by an integrated approach to watershed management (Agarwal et al., 2019, Górska, 2020, Omar and Moussa,2016, Mostafa and Sarjoughian,2021). Fig. 4 summarizes the steps followed for the realization of the model.

Data for 2017 are used in our study for all water resources and water demand by municipality as a unit. For this purpose, we have on the one hand for each municipality a drinking water demand site, a farming water demand site and an industrial water demand site if it exists, considering evaporation as a demand for water, and on the other hand water supply elements such as groundwater extracted from aquifers and surface water from the dam and hill reservoirs and finally rainfall and runoff in the sub-basin (Fig.4). The database of the study area which allows the application of the model is collected from many administrations, such as Hydrographic Basin Agency, National Agency for Hydraulic Resources, National Meteorological Office, Directorate of Agricultural Services, National Statistics Office, National Office for Irrigation Perimeters, Algerian Water and the two existing meteorological stations in the middle Seybouse sub-basin Hammam Debagh and Belkhier stations for hydrological data.

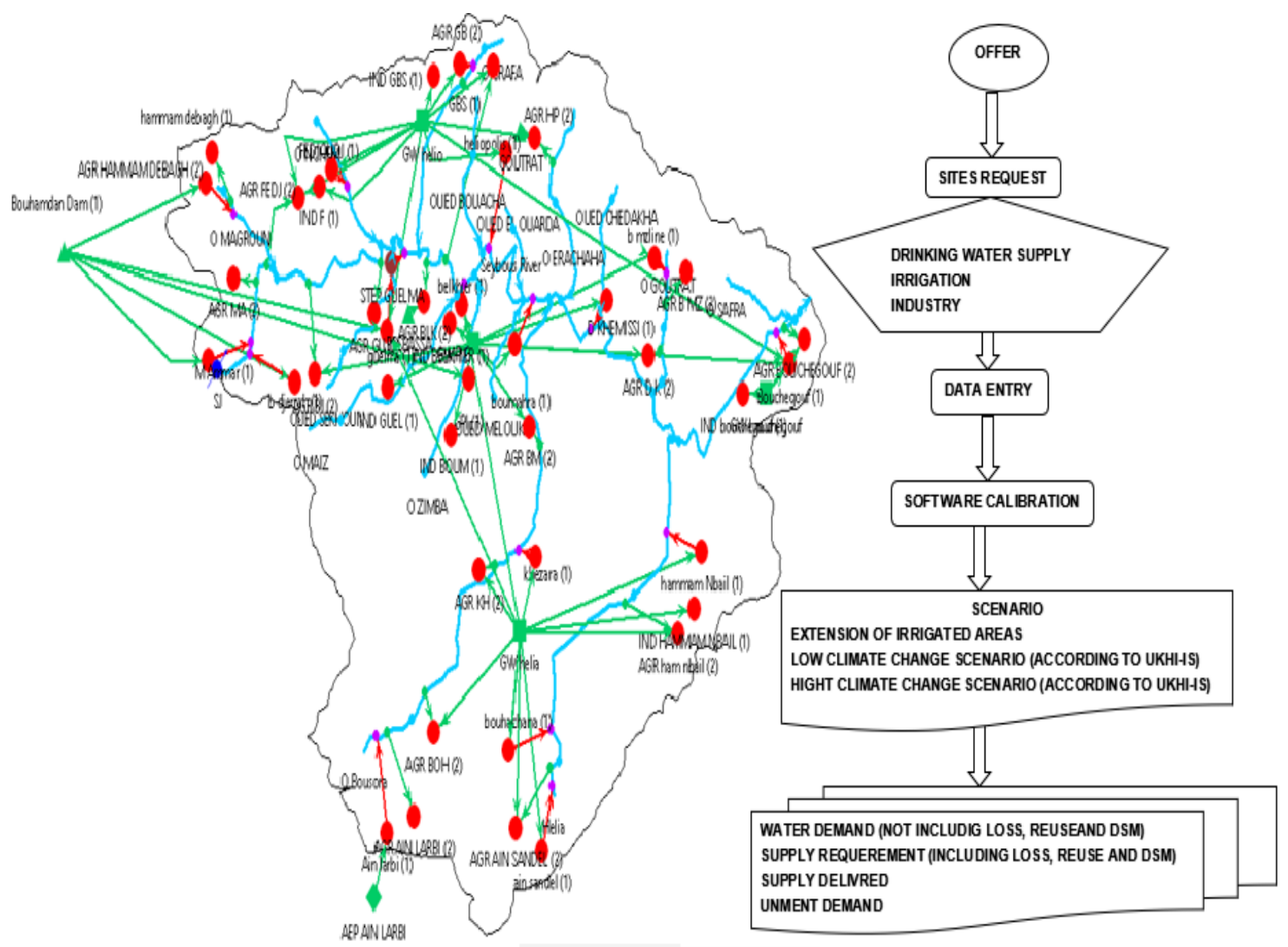

Fig. 4. Conceptual model of water resources distribution.

In this part, the time parameters should be resolved. Create a year of current accounts for the project. for that, we have chosen the year 2017 as the reference year for all information on the system: 
demand sites, supply data, consumption, transmission link. The baseline scenario is established from the current account, in which all data base are introduced, to simulate the same system evolution without intervention (SEI,2008). For our study, the reference scenario covers the period (2020 - 2050), It translates simply a projection of trends current without major changes, and serves as a point of comparison for others Scenarios in which changes in system data can be realized. To carry out our work well, we have adopted the scenarios: climate change with its two hypotheses (high and low) and extension of irrigated areas. The study duration is from the year 2020 until 2050.

\subsection{Climate change scenarios $(\mathrm{CCS})$}

According to the results of the national project ALG / 98 / G31, northeastern Algeria is subject to the consequences of global warming with reduced inputs and increased temperature (Abdelguerfi, 2003). According to the UKHI (United Kingdom Meteorological Office High Resolution). model, the IPCC "IS92a" scenario with the two high and low assumptions was adopted (Table 1).

Table 1.

The GIEC “IS92a”" scenario with the two high and low hypotheses.

\begin{tabular}{|c|c|c|c|c|c|}
\hline \multirow{2}{*}{ Season } & \multirow{2}{*}{$\begin{array}{c}\text { Climatic } \\
\text { parameters }\end{array}$} & \multicolumn{2}{|c|}{2020} & \multicolumn{2}{|c|}{2050} \\
\cline { 3 - 6 } & Low & High & Low & High \\
\hline \multirow{2}{*}{ Autumn } & $\mathrm{T}^{\circ} \mathrm{C}(+)$ & 0.8 & 1.1 & 1.2 & 2.2 \\
\cline { 2 - 6 } & $\mathrm{P} \%(-)$ & 6 & 8 & 10 & 15 \\
\hline \multirow{2}{*}{ Winter } & $\mathrm{T}^{\circ} \mathrm{C}(+)$ & 0.65 & 0.8 & 0.95 & 1.6 \\
\cline { 2 - 6 } & $\mathrm{P} \%(-)$ & 10 & 10 & 16 & 16 \\
\hline \multirow{2}{*}{ Spring } & $\mathrm{T}^{\circ} \mathrm{C}(+)$ & 0.85 & 0.95 & 1.25 & 1.9 \\
\cline { 2 - 6 } & $\mathrm{P} \%(-)$ & 5 & 9 & 10 & 20 \\
\hline \multirow{2}{*}{ Summer } & $\mathrm{T}^{\circ} \mathrm{C}(+)$ & 0.85 & 1.05 & 1.25 & 2.1 \\
\cline { 2 - 6 } & $\mathrm{P} \%(-)$ & 8 & 13 & 15 & 22 \\
\hline
\end{tabular}

In this study, the statistical downscaling model LARS-WG 6.0, which is a stochastic generator of meteorological conditions based on observed data (Semenov et al. 1998), was used to extract future precipitation and temperatures at the local scale from the MCGs of CMIP5 under two scenarios RCP 4.5 and RCP 8.5. It should be noted that all climate model outputs are in general biased due to the systematic errors that occur after the discretization and the spatial averaging in grid cells and due to the imperfect conceptualization of the models themselves (Teutschbein and Seibert 2012). Using the models' outputs as they are can lead to significant errors in impact evaluations. Thus, it is necessary to apply bias correction to the models' outputs before their use in impact analyzes (Teutschbein and Seibert 2012). The version 6.0 of LARS-WG (Semenov \& Stratonovitch, 2015)) provides for a chain of measurement allowing the correction of the bias of the GCM outputs at the time of the extraction and the generation of climate data from the CMIP5 models.

\section{RESULTS AND DISCUSSION}

\subsection{Irrigated land extension scenario (ILES)}

Due to the low use of irrigated land in relation to useful agricultural land (UAA), the agricultural services of the Guelma province, foresees an increase rate of 50\% every 10 years in these irrigated lands. (Five- years project 2014-2019 (WRD, 2017). 
In the three scenarios adopted and for the seventeen municipalities of the watershed, the number of inhabitants increases from 346,342 in 2017 to 688,091 inhabitants in 2050, i.e., an increase of $50.33 \%$ and the surface area of irrigated land jumps from $14,302.5$ ha (i.e. $18.65 \%$ of UAA) in 2017 to $37,228.61$ ha, or (48.54\% of UAA) in 2050 (Fig. 5).
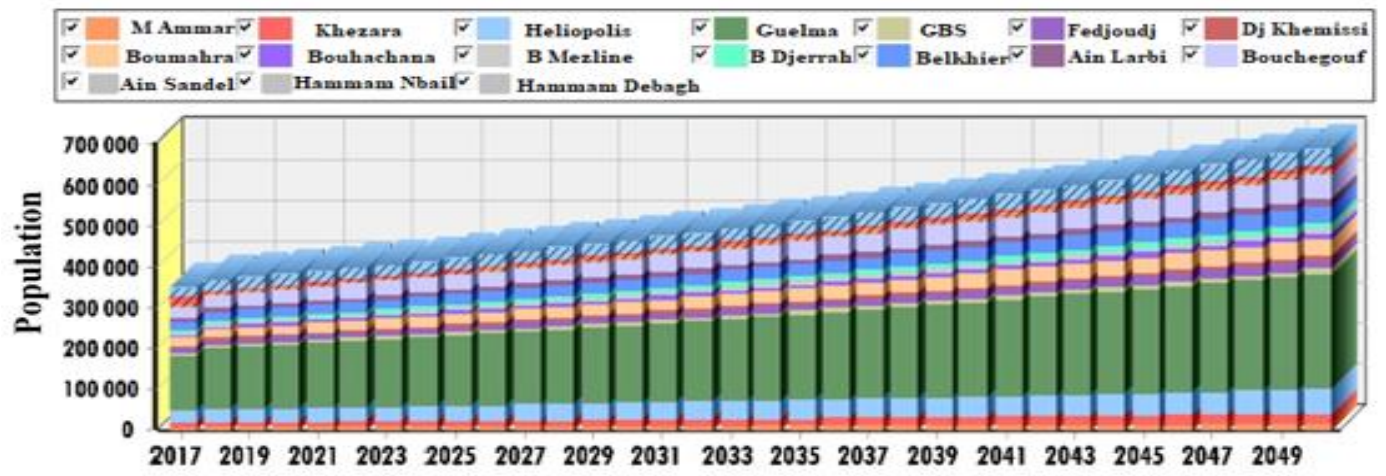

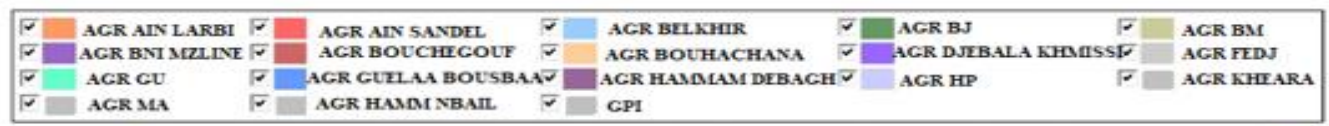

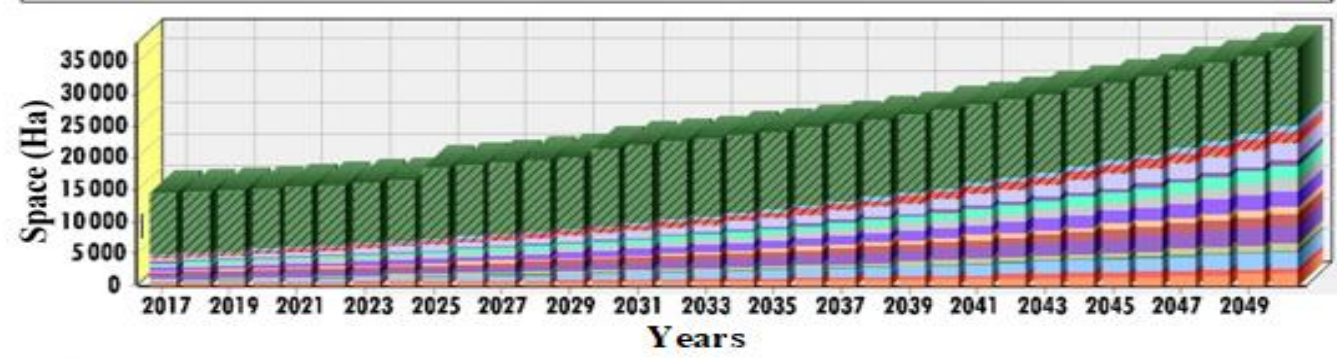

Fig. 5. Evolution of inhabitants and irrigated areas by scenarios.

For water needs, we notice a clear increase from a volume of $80.92 \mathrm{hm}^{3}$ to more than $194.83 \mathrm{hm}^{3}$ in all the scenarios adopted, mainly linked to the extension of the irrigated land areas. For the reference scenario, a slight increase in water needs is recorded, varying from $80.92 \mathrm{hm}^{3}$ in 2017 to $91.10 \mathrm{hm}^{3}$ in 2050, following a moderate increase in the population (Fig.6).

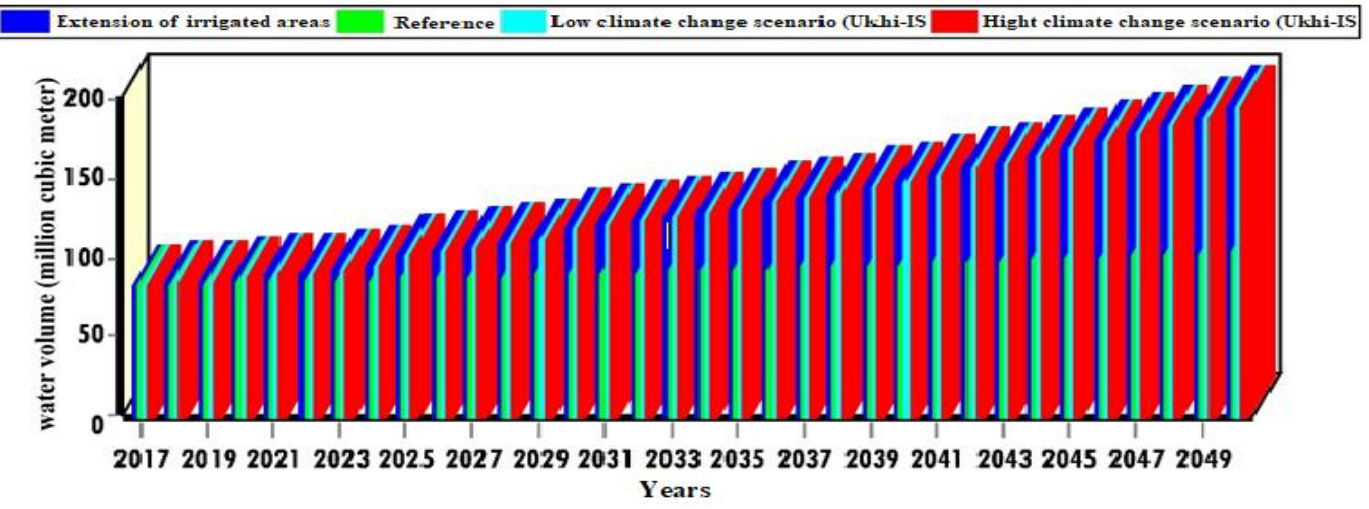

Fig.6. Water demand by scenario (2017-2050). 
The total water demand (including losses) in the study area is marked by a considerable increase in all the scenarios adopted (SCC and SETI), going from a volume of $105.23 \mathrm{hm}^{3}$ in 2017 to 226.95 $\mathrm{hm}^{3}$ in 2050 for the reference scenario (RS), the increase in demand is low during the simulation period, ranging from $105.23 \mathrm{hm}^{3}$ in 2017 to $114.36 \mathrm{hm}^{3}$ in 2050 (Fig.7).

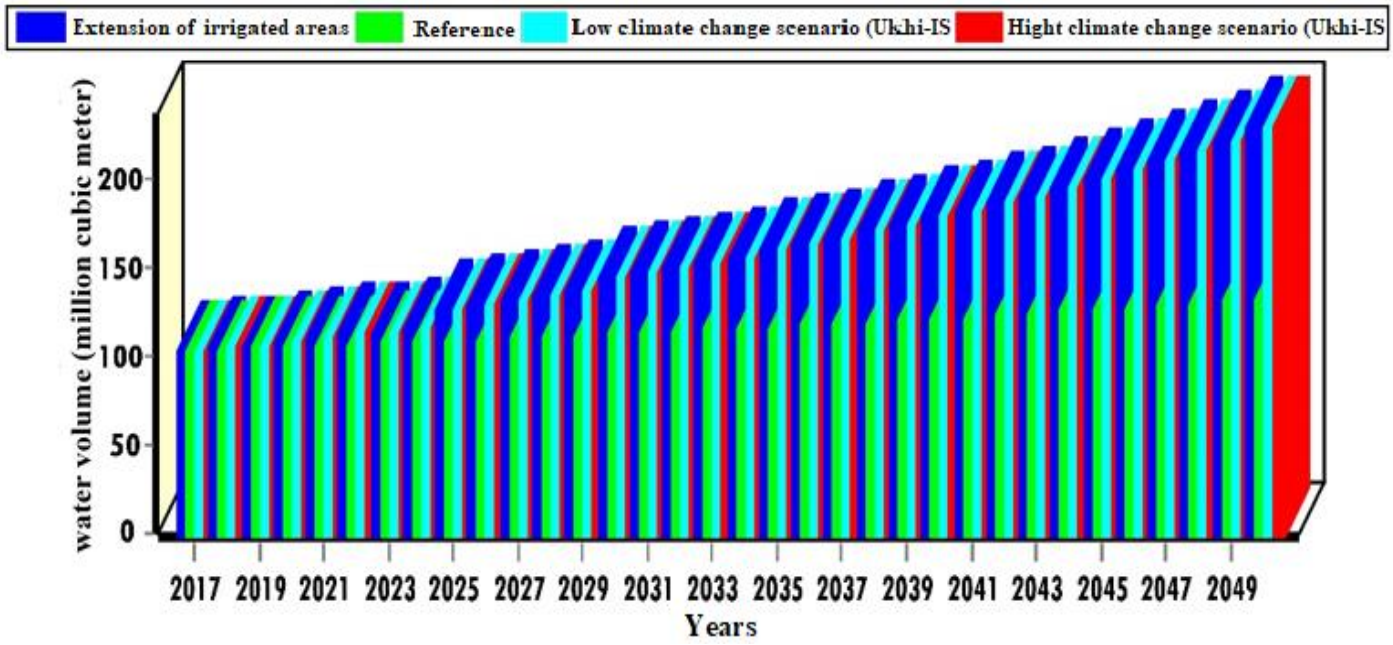

Fig.7. Water total demand by scenario (2017-2050).

For distributed water during 2017 and for all the scenarios adopted, the volume of water distributed is around $45.75 \mathrm{hm}^{3}$. This volume increases to $89.08 \mathrm{hm}^{3}$ in 2025 , which can be explained by the forecast to achieve an irrigation perimeter of 1700 ha in the Khezaras municipality and the construction of another irrigation perimeter of $1000 \mathrm{Ha}$ at Bouchegouf by 2030. In the year 2050 this same volume increases to reach $123.39 \mathrm{hm}^{3}$ (Fig.8).

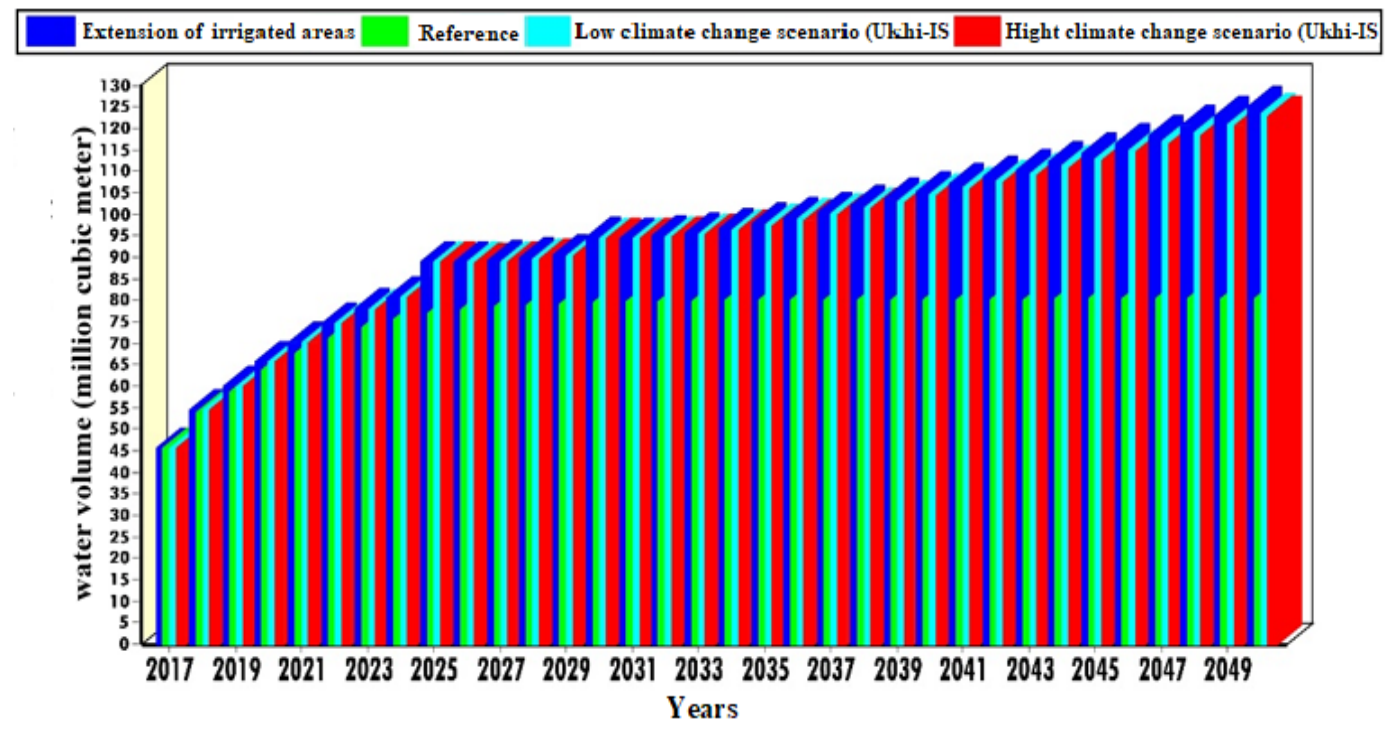

Fig. 8. Water distributed by scenario (2017-2050). 
According to the Fig. 9, we see an unmet need for water estimated at a volume of $55.5 \mathrm{hm}^{3}$ during the reference year 2017. This deficit distributed between irrigation water (around $45 \mathrm{hm}^{3} /$ year) and drawdown slicks are mainly due to the lack of precipitation during this year. From the year 2025 begins a change resulting in an increase in the deficit interpreted by a lack of $104.20 \mathrm{hm}^{3}$ at the end of the simulation period (2050).

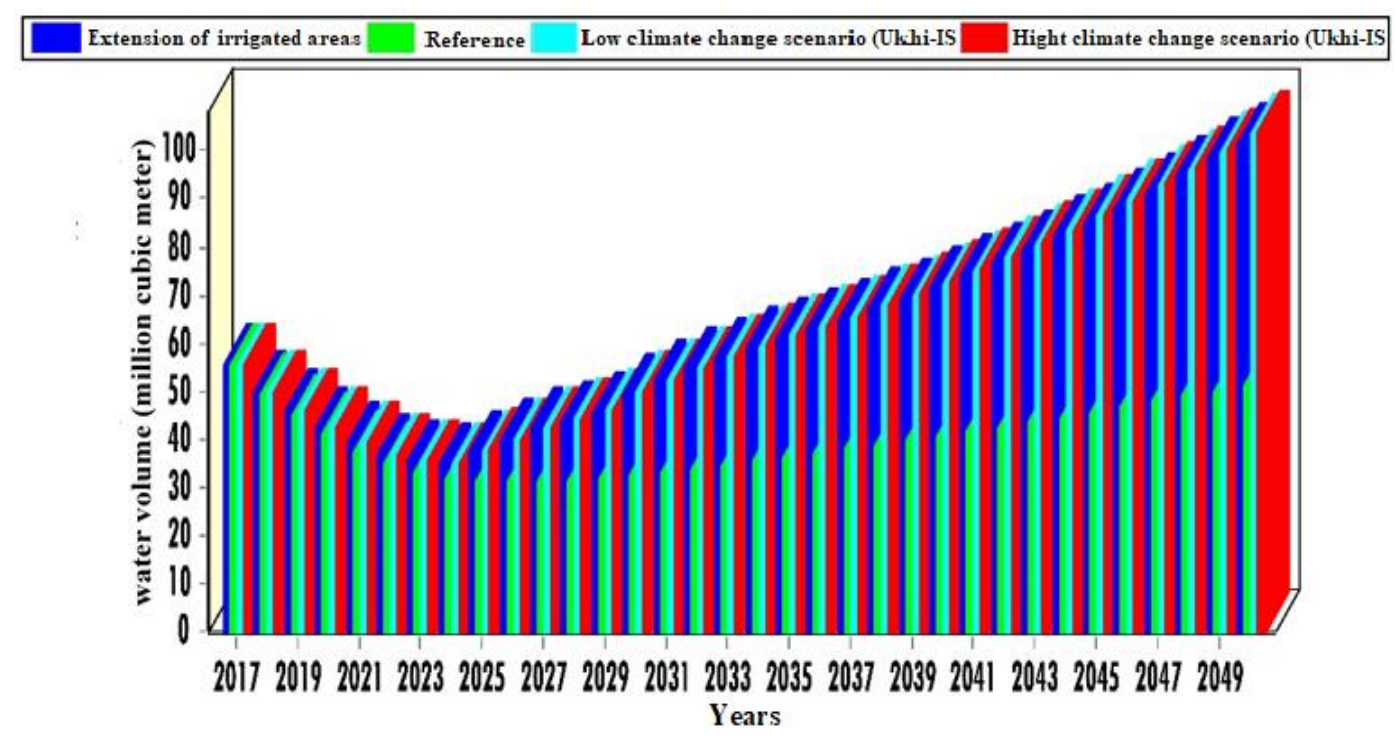

Fig. 9. Unmet water demands by scenario (2017-2050).

\section{CONCLUSION}

In this study we chose the WEAP software which gave us the opportunity to use our data on water resources to simulate their evolution and their users by 2050. The results obtained showed that the middle Seybouse basin is already under water stress, it suffers from water scarcity and is sensitive to drought conditions. The number of inhabitants increases from 346,342 in 2017 to 688,091 inhabitants in 2050, and the surface area of irrigated land jumps from 14,302.5 ha in 2017 to $37,228.61$ ha in 2050. The amount of unmet demand for water is greater than the water supplied; available resources such as mean rainfall and outgoing water collection and storage infrastructure, including natural groundwater reservoirs, have failed to meet current and future needs in the middle Seybouse watershed. The scenarios of climate change and extension of irrigated land chosen for this study, show a water deficit from the reference year 2017 with a shortage of $50.5 \mathrm{hm}^{3}$ which will be increasing to $104.20 \mathrm{hm}^{3}$ in 2050 . The catchment area of the middle Seybouse presents a glaring shortage at the end of the scenarios.

\section{RECOMMANDATIONS}

It is urgent that those responsible for water participate seriously in solving this problem by using other resources, namely unconventional water, desalination and exploitation of surface water through the study and realization of dams.

\section{Acknowledgements}

The data presented in this article are the results of investigations which we carried out with the assistance of the services of hydraulics, agriculture, industry and municipalities. We are very grateful to them. 


\section{R E F E R E N C E S}

Abdelguerfi. A (2003). Needs assessment in terms of capacity building necessary for the assessment and reduction of risks threatening the elements of biological diversity in Algeria Report number: Synthesis Report (Volume 5) Affiliation: Consultation Report within the framework of the UNDP Project-FEMMATE, ALG97 / G31 " Action Plan and National Strategy on Biodiversity.

Agarwal, S., Patil, J.P., Goyal, V.C. et al. (2019). Assessment of Water Supply-Demand Using Water Evaluation and Planning (WEAP) Model for Ur River Watershed, Madhya Pradesh, India. J. Inst. Eng. India Ser. A 100, 21-32, https://doi.org/10.1007/s40030-018-0329-0.

Al-Shutayri, A.S., Al-Juaidi, A.E.M. (2019). Assessment of future urban water resources supply and demand for Jeddah City based on the WEAP model. Arab J Geosci 12, 431, https://doi.org/10.1007/s12517-019-45947.

Alemu, Z.A., Dioha, M.O. (2018). Modelling scenarios for sustainable water supply and demand in Addis Ababa city, Ethiopia. Environ Syst Res 9, 7 (2020). https://doi.org/10.1186/s40068-020-00168-3.

Algerian national statistics office (2018) Unpublished report.

Fard, M., D., Sarjoughian, H., S. (2021). A restful framework design for componentizing the water evaluation and planning (WEAP) system, Simulation Modelling Practice and Theory, 106, 102199, ISSN 1569190X, https://doi.org/10.1016/j.simpat.2020.102199.

Gaud. F (1974). Hydrogeological study of the alluvial aquifer of Guelma. Unpublished report.

Górska, M. (2020). Optimizing the water allocation system in the Dutch region by adopting the WEAP model.

Husain S.A., Rhyme N.H.M. (2021). Decision Support Method for Agricultural Irrigation Scenarios Performance Using WEAP Model. In: Abdul Karim S.A. (eds) Theoretical, Modelling and Numerical Simulations Toward Industry 4.0. Studies in Systems, Decision and Control, 319. Springer, Singapore. https://doi.org/10.1007/978-981-15-8987-4_.

Höllermann, B., Giertz, S. \&Diekkrüger, B. Benin (2010). 2025-Balancing Future Water Availability and Demand Using the WEAP 'Water Evaluation and Planning' System. Water Resources Management, 24, 3591-3613 https://doi.org/10.1007/s11269-010-9622-z.

Hamlat, A., Errih, M. \&Guidoum, A. (2013). Simulation of water resources management scenarios in western Algeria watersheds using WEAP model. Arab J Geosci 6, 2225-2236, https://doi.org/10.1007/s12517-0120539-.

Kiniouar, H., Hani, A., Kapelan, Z. (2017). Water Demand Assessment of the Upper Semi-arid Sub-catchment of a Mediterranean Basin. Energy Procedia, 119, 870-882, ISSN 1876-6102, https://doi.org/10.1016/j.egypro.2017.07.140.

Kahlerras, M., Meddi, M., Benabdelmalek, M. et al. (2018). Modeling water supply and demand for effective water management allocation in Mazafran basin (north of Algeria). Arab J Geosci 11, (547), https://doi.org/10.1007/s12517-018-3869-8

Klose S., Reichert B., Lahmouri A. (2008). Management Options for a Sustainable Groundwater Use in the Middle Drâa Oases under the Pressure of Climatic Changes. In: Zereini F., Hötzl H. (eds) Climatic Changes and Water Resources in the Middle East and NorthAfrica. Environmental Science and Engineering. Springer, Berlin, Heidelberg. https://doi.org/10.1007/978-3-540-85047-2_14.

Lévite, H., Sally, H., Cour, J. (2003). Testing water demand management scenarios in a water-stressed basin in South Africa: application of the WEAP model. Physics and Chemistry of the Earth, Parts A/B/C, 28, (2027), 779-786, ISSN 1474-7065, https://doi.org/10.1016/j.pce.2003.08.025.

Omar, M., Moussa, M.A., (2016). Water management in Egypt for facing the future challenges. Journal of Advanced Research, 7 (3), 403-412, ISSN 2090-1232, https://doi.org/10.1016/j.jare.2016.02.005.

Saadoun, A., Ali, M.F., Abd Rahman, N.F., Khalid, K. (2014) An Assessment of Water Demand in Malaysia Using Water Evaluation and Planning System. In: Hassan R., Yusoff M., Ismail Z., Amin N., Fadzil M. (eds) In CIEC 2013. Springer, Singapore. https://doi.org/10.1007/978-981-4585-02-6_64.

SEI (2008) WEAP (Water Evaluation and Planning): User Guide for WEAP-21. Stockholm Environment Institute, Boston.Soc. Civ. Eng. 81, 695-721.

Seiber, J., Swartz, C., \& Huber-Lee, A. (2005). User guide for WEAP21, Stockholm Environment Institute, Tellus Institute, $176 \mathrm{pp}$. 
Semenov, M. A. Brooks R. J. Barrow E. M. Richardson C. W. (1998). Comparison of the WGEN and LARS-WG stochastic weather generators for diverse climates. Climate Research 10 (2): 95-107. https://doi.org/10.3354/cr010095.

Shahraki, et al. (2016). An application of WEAP model in water resources management considering the environmental scenarios and economic assessment case study: Hirmand Catchment. Modern Applied Science 10 (5): 49-56.

Shiklomanov, I. A., Rodda J. C. (2003). World water resources at the beginning of the twenty-first century. Cambridge, UK, Cambridge University Press.

Singh, A. (2014). Conjunctive use of water resources for sustainable irrigated agriculture. Journal of Hydrology, 519, 1688-1697.

Sulis, A., Sechi, G. M. (2013). Comparison of generic simulation models for water resource systems. Environmental Modelling and Software, 40, 214-225.

Teutschbein, C, Seibert, J. (2012). Bias correction of regional climate model simulations for hydrological climate-change impact studies: review and evaluation of different methods. J. Hydrol. 456-457:1229. https://doi.org/10.1016/j.jhydrol.2012.05.052.

UKHI (United Kingdom Meterological Office High Resolution) The Met Office is the UK's national weather service. We provide essential weather services and leading climate science around the world. https://www.metoffice.gov.uk/research/climate/maps-and-data/regional-climates/index.

Vila, J. M. (1980). The Alpine chain of eastern Algeria and the Algerian-Tunisian borders, 3 rd cycle thesis, 663 pp, Univ.Paris VI, Orsay.

Water resources department (2018) data on the quantities of water distributed.

WEAP 21: (http://www.weap21.org/).

Xue Li, Yue Zhao, Chunli Shi, JianSha, Zhong-Liang Wang, Yuqiu Wang (2015) Application of Water Evaluation and Planning (WEAP) model for water resources management strategy estimation in coastal Binhai New Area, China. Ocean \& Coastal Management, 106, 97-109, ISSN 0964-5691, https://doi.org/10.1016/j.ocecoaman.2015.01.016.

Yates, D., Purkey, J., Seiber, A., Huber-Lee, A., Galbraith, H., West, J., Herrod-Julius, S. (2005) A physicallybased, water resource planning model of the Sacramento Basin, California USA. Am. Soc. Civ. Eng. 81, 695-721.

Yazdanpanah, T., Khodashenas, S. R., Davari, K., Ghahraman, B. (2008). Water resources management in a Watershed with WEAP model (A case study of Azghad watershed). Journal of Agriculture Science and Technology, 22 (1), 213-221.

Zerkaoui, L., Benslimane, M., Hamimed, A. (2018). Planning and systematic management of water resources by the WEAP model, case of the Mabtouh watershed (northwestern Algeria). Arabian Journal of Geosciences 11 (24): 1-17. 